\title{
INSURING SUPPLIER CREDIT RISK IN EXPORTS TO PROMOTE EXPORT GROWTH AND ECONOMIC DEVELOPMENT
}

DOI: 10.17261/Pressacademia.2018.1003

JEFA- V.5-ISS.4-2018(5)-p.359-372

\section{Muge Cetiner ${ }^{1}$, Selda Eke ${ }^{2}$}

${ }^{1}$ Istanbul Kultur University, Halkalı Merkez Mahallesi, Basın Ekspres Caddesi, Istanbul, Turkey. m.cetiner@iku.edu.tr, ORCID: 0000-0003-1248-5335

${ }^{2}$ Istanbul Kultur University, Halkalı Merkez Mahallesi, Basın Ekspres Caddesi, Istanbul, Turkey. seldaeke@yahoo.com , ORCID: 0000-0003-4162-3549

Date Received: October 15, 2018

Date Accepted: December 12, 2018

To cite this document

Cetiner, M., Eke, S. (2018). Insuring supplier credit risk in exports to promote export growth and economic development. Journal of Economics, Finance and Accounting (JEFA), V.5(4), p.359-372.

Permemant link to this document: $\underline{\mathrm{http}} / / /$ doi.org/10.17261/Pressacademia.2018.1003

Copyright: Published by PressAcademia and limited licenced re-use rights only.

\begin{abstract}
Purpose- The purpose of this study is to evaluate the effectiveness of the insured trade credit on the international trade abroad and in our country and to raise awareness about the issue that has great potential for growth in our country in the future.

Methodolgy- The studies investigating the effect of the insured open account trade by private and officially supported export credit agencies on the development of exports and in general international trade were examined. The effect of export growth on economic development has been examined in order to assess the impact of export credit insurance. The fundamental concepts with the literature review have been summarized.

Findings- Through the literature review, the following facts have been obtained. Supplier credit leads to the increase in sales of the supplier and that in turn leads to company growth. It is also an important financing source for the buyer who buys on credit also sells on credit and that leads to an increase in trade flows. It is complementary and alternative to bank loans especially in the periods of financial constraints when the companies are in need of working capital finance. Insured open account trade has a quite significant effect on increasing the exports of the country. At macro level, there is a dual causality relationship between export growth and economic development.

Conclusion- As the result of the study, it has been concluded that the insured trade credit promotes the growth of trade flows and supply chains that would lead to the growth in trade volumes and economic growth.
\end{abstract}

Keywords: Supplier credit, trade credit, open account trade, export credit insurance, credit insurance

JEL Codes: G22, F18, H81

\section{IHRACAT ARTIŞININ VE EKONOMIK BÜYÜMENIN SAĞLANMASINA YÖNELIK OLARAK IHRACATTA TEDARIKÇi KREDI RISKININ SIGORTALANMASI}

\section{ÖZET}

Amaç- Bu çalışmada amaçlanan gerek ülkemizde gerekse yurtdışında sigortalanmış kredili ticaretin dış ticaret üzerindeki etkisinin araştırılması ve konunun önemi üzerinde farkındalık yaratarak ülkemizde gelecekte çok büyüyebilecek bir potansiyele dikkat çekmektir. Yöntem- Resmi destekli ihracat kredi sigortası ya da özel sektör kredi sigortası kuruluşları tarafından sigortalanan açık hesap ticaretin, ihracatın ve genel olarak uluslararası ticaretin gelişimine olan desteği konusunda yapılan çalışma örnekleri incelenmiştir. İhracatın ekonomik büyüme üzerindeki etkisi üzerinde durularak, ihracat kredi sigortası desteği irdelenmiştir. Temel kavramlar ve literatür çalışmaları özetlenmiştir.

Bulgular- Literatür taraması sonucunda elde edilen bulgular şunlardır: Tedarikçi kredisi, tedarikçi firmaların satışlarını arttırarak firma büyümesine katkı sağlamaktadır. Alıcı firmalar için de önemli bir finansman kaynağı olmaktadır. Alıcı şirketin kendisi de müşterilerine kredili satış yapabildiğinden, ticari akımlarda artış sağlanmaktadır. Tedarikçi kredisi, işletme sermayesi finansman ihtiyacının karşılanmasında, özellikle finansal sıkışıklıkların olduğu dönemlerde şirketler için banka kredisine alternatif ve tamamlayıcı bir finansman kaynağı olmaktadır. Açık hesap ticaretin sigortalanması, ülkenin ihracatını arttırma konusunda son derece önemli bir role sahiptir. Makro düzeyde, ihracatın büyümesi ile ekonomik gelişme arasında da iki yönlü bir nedensellik ilișkisi bulunmaktadır.

Sonuç- Çalışmada sigortalanmış kredili satışların ticari akımlarda büyümeyi destekleyeceği, tedarik zincirlerinin büyümesine neden olmaları sonucunda da, ticaret hacminin artmasına, ekonomik büyümeye katkı sağlayacakları sonucuna ulaşılmıştır.

Anahtar Kelimeler: Tedarikçi kredisi, kredili ticaret, açık hesap ticaret, ihracat kredi sigortası, kredi sigortası JEL Kodları: G22, F18, H81 


\section{Giriş}

Kredili ticarette tedarikçiler mal ve hizmet bedellerini teslimatta peşin almak yerine belirli bir vadenin sonunda almayı kabul ederler. Tedarikçi alıcıya ödemesi için bir vade tanıyarak alıcıya kısa vadeli bir kredi (trade credit) açmaktadır (Nilsen J. H., 1999). Tedarikçi teslim edilmiş mallarla ilgili olarak alıııya ödemesini gecikmeli olarak yapmak konusunda bir imtiyaz tanımaktadır. (Cunat, 2004). Bu işlemin tedarikçi açısından önemi rekabet avantajı yaratarak satışlarında artış sağlamasındadır. (Li, 2014). Tedarikçinin mal bedelini peşin almak yerine belli bir ödeme vadesine bağlı olarak tahsil etmesi finans literatüründe alacaklara yapılan yatırım olarak tanımlanır. Tedarikçinin işletmenin alacaklarına yaptığı bu yatırımı karşılığında belirli bir getiri elde etmesi beklenir. Alıcı açısından ise bu bir finansman imkânıdır. (Long, Malitz, \& Ravid, 1993) Şirketler arası kredi ( intercompany credit) veya kredili ticaret, kredili satış ( trade credit, credit sales) olarak da adlandırılan, tedarikçi kredisi (supplier credit) alıcıya banka kredisi benzeri bir finansman imkânı sağlar. Alıcının bankasından sağlayabileceği işletme sermayesi kredisinin yerine geçer. (Meltzer, 1960) Tedarikçi açısından vadeli satış ürünün satış fiyatına paranın zaman değeri olarak bilinen bir faiz farkının ilave edilmesini gerektirir. Bir başka deyişle, vadeli satılan bir malın fiyatının ise belirli bir iskonto oranı ile hesaplanan peşin fiyatı vardır. Tedarikçinin nakit iskonto uygulayarak peşin satış yapması satışlarının beklenilenden az olmasına neden olabilir. Aynı şekilde vadeli satış yaparak satışlarını arttırması mümkündür. Ancak bu şekilde elde edeceği ilave kazancın alacaklara yapılan ilave yatırımdan dolayı oluşan maliyeti aşması gereklidir. (Özdemir, 1999) Tedarikçinin kredili satış yapmasının sebeplerine ilişkin birçok teori vardır. İşlem maliyeti teorisine göre kredili ticaret alıcı ve satıcı arasındaki işlem maliyetini azaltır. Ödeme vadesi konusunda önceden bir anlaşma sağlanır ve faturalar bu ödeme vadesinde toplu olarak ödenir. Tedarikçi ile alıcı arasında bir hesap ilişkisi vardır. Belirli dönemlerde mutabakat yapılır. Finansal aracılık teorisine göre tedarikçilerin finansal açıdan daha güçlü kuruluşlar olması bankalardan kredi kullanma maliyeti konusunda bir avantaj elde etmesine sebep olmaktadır. Tedarikçiler bu avantajı vadeli satış yaparak alıcılarına kaydırmaktadırlar. Fonların akışı büyük firmalardan finansal açıdan göreceli olarak daha zayıf firmalara aktarılmaktadır. Kredili satış yapılmasının sebeplerinden biri talep dalgalanmalarında vade değişikliğinin yapılması yoluyla alıı için efektif fiyat değişikliğinin sağlanmasıdır. Fiyat ayırımcılığı olarak bilinen bu teoriye göre tedarikçiler diğer kredi alternatiflerine ulaşmakta zorluk çeken riskli müşteri grubuna vadeli fiyat uygulamak yoluyla fiyat farklılı̆ı yaratmaktadırlar. Kredi değerliliği yüksek firmalar bu fiyat farkını üstlenmek istemezler ve peşin ödeme yoluna giderler. Alıcıya tanınan vade ile riski nispeten yüksek müşteri fiyat dışında bir de ilave finansman avantajı elde etmektedir. (Petersen \& Raghuran, 1997) Smith, alıcının mal bedelini peşin ödemek yerine mal tesliminden sonra ödemesinin ürünün kalitesi hakkında bir kontrol imkânı sağladığını ve bu kontrol imkânının alıcının düzenli siparişleri için bir süreklilik sağladığını söylemiştir. Bu durum asimetrik bilginin azaltılması konusunda da etkin olmaktadır. (Smith, 1987) Kredili satışlarda temerrüt riskinin de dikkate alınması gereklidir. Kredi vadesinin uzatılması satışları arttıran bir unsurken, artan belirsizliğe bağlı olarak kredi riski de artar. (Wieczorek, 2005)

İhracatta tedarikçinin kredili satışları dolayısıyla taşıdığı risk birkaç nedene bağlı olarak daha yüksektir. Bunlardan biri tedarikçinin potansiyel müşterisi hakkında bilgi edinme konusunda yaşayabileceği sıkıntıdır. Tedarikçi, ticari riskin yanısıra politik risklerle karşılaşabilir. Tahsilat problemlerinin oluşması durumunda alıcının bulunduğu ülkede başlatılan tahsilat işlemleri o ülkenin kanunlarına göre yürütüleceğinden tahsilatın etkinliği konusunda sıkıntılar yaşanabilir. Uluslararası ticaretin gittikçe açık hesap ödeme şekli ile yürütülmesi, tedarikçinin karşılaşacağı riskin boyunu arttırmaktadır. Açık hesap ticarette, tedarikçi lehine banka aracılığıyla verilen herhangi bir garanti mevcut değildir. Ödeme şekillerinden mal mukabili ticaret olarak bilinen açık hesap ticarette tedarikçi malı alıcıya sevk eder ve faturasını düzenler. Alıcı malları teslim alır ve faturada yazılı ödeme vadesinde doğrudan ihracatçıya ödeme yapar Artan rekabet sonucunda tedarikçi bu riski taşımakta ve riskin azaltılması konusunda banka dışı çözümlere ve alternatif finansman tekniklerine yönelmektedir. Kredili ticaretin sürdürülebilirliği tedarikçinin karşılaşacağı bu risklerin teminat altına alınması yoluyla mümkündür. İhracatçının vadeli ve açık hesap satışları dolayısıyla karşılaşacağı ticari ve politik riski teminat altına alan finansal araçlardan biri ticari alacak sigortası (trade credit insurance ) olarak da bilinen kredi sigortasıdır. Özel sektör kuruluşları ve resmi destekli kredi sigortası kuruluşları (export credit agencies, ECAs) tarafından düzenlenen bu poliçeler kısa vadeli ticari alacağın fatura vadesinde tahsil edilememesi riskini teminat altına alırlar. (Çetiner \& Eke, 2018)

Bu çalışma 4 bölümden oluşmaktadır. İlk bölümde, tedarikçi kredisinin teminat altına alınmasında kullanılan kredi sigortası ile ilgili bilgilere yer verilerek ihracat kredi sigortası şirketlerinin standart kredi sigortası poliçesi düzenlemek konusundaki uygulamalarının yanı sıra resmi destekli ihracat kredi sigortası kuruluşlarının diğer ürün ve uygulamalarına yer verilmektedir. İkinci, üçüncü ve dördüncü bölümlerde literatür çalışmalarından yararlanılmıştır. İkinci bölümde, tedarikçi kredisinin kredili ticaretin büyümesi yoluyla ticarete etkisi incelenmektedir. Üçüncü bölümde, sigortalanmış tedarikçi kredisinin (insured supplier credit, insured trade credit) ihracat ve uluslararası ticaret üzerindeki etkisi analiz edilmiştir. Dördüncü bölümde, ihracatın ekonomik büyüme üzerindeki etkisini inceleyen çalışmalara başvurulmuştur.

\section{KREDI SIGORTASI KURULUŞLARININ ÜRÜN VE UYGULAMALARINDAKI FARKLILIKLAR}

Uygulamada standart olarak bilinen kısa vadeli kredi sigortası ile mal ve hizmet tedarikinde bulunan tedarikçiler açık hesap ve kredili satışlarından doğan ticari risklerini sigortalamaktadırlar. Poliçelerde tedarikçiler sigortalı konumundadırlar. Tedarikçilerin mal sattığı müşterileri ise kredi sigortası şirketlerinin ödeme riskini taşıdığı borçlu konumundaki şirketler, kredi sigortası terminolojisinde alııı konumundaki şirketlerdir. Alıcılar, sigortalı ile aynı ülkede ise yurtiçi kredi sigortaları, 
şayet alıcılar başka bir ülkede ise ihracat kredi sigortaları söz konusu olmaktadır. Sigortalanmış ticari alacak riskinin, örneğin, mal ve hizmetlerin teslimatı gibi, bir ticari işlemle doğrudan bir bağlantısı olmak zorundadır. Kısa vadeli ticari işlemlerle ilgili olarak düzenlenen kısa vadeli yurtiçi veya ihracat poliçelerinde teminat kapsamına alınan kredi riskine ilişkin vade genellikle azami 1 yıldır. Genellikle özel sektör kredi sigortası kuruluşları tarafından düzenlenen kısa vadeli bu poliçelerle tedarikçiler yurtiçi ya da ihracattan kaynaklanan ticari riskleri güvence altına alırlar. (Çetiner \& Eke, 2018) Bu poliçelerde, yükleme sonrası karşılaşılabilecek ticari riske ilişkin verilmiş garantiye ek olarak, bazı durumlarda örneğin özel üretim mallar söz konusu olduğunda yükleme öncesi riskler de teminat altına alınmaktadır. Alııı ile kontratın imzalanması ile başlayan bu teminatta, alıcının henüz yükleme yapılmadan evvel iflası sözkonusu olursa sigorta poliçesine yapılacak bir ekle ile yükleme öncesi riskler de teminat altına alınabilir. (Becue, 2013)

Resmi destekli ihracat kredi sigortası kuruluşları ülke hükümetlerinin ülke ihracatını desteklemek üzere kurdukları kamu ya da yarı kamu statüsündeki kuruluşlardır. Bu kuruluşların ihracat kredi sigortası programlarının bazıları özel sektör kredi sigortası kuruluşları tarafından yönetilmektedir. Özel sektör kuruluşları bir taraftan kendi adlarına faaliyet gösterirken, diğer taraftan ülkenin resmi kuruluşu adına programı yönetmekle ilgili olarak faaliyet gösterirler ve genellikle kredi vadesi 2 yıl üzeri olan riskleri teminat altına alırlar. Bu kuruluşlar, $O E C D$ ve diğer direktiflere göre faaliyetlerini sürdürürler. Avrupa Birliği üye ülkelere OECD ülkelerine yönelik olarak bu kuruluşların iki yıldan kısa vadeli ticari riskleri teminat almak üzere devlet destekli sigortalama faaliyeti yapmasına izin vermemektedir. Bu alan özel sektör kuruluşlarına tanınmışır. Ancak diğer ülkeler için bu kısıtlama yoktur. Birçok kredi sigortası kuruluşu daha kısa vadeli riskleri de sigortalamaktadır. Bu kuruluşlar, ülkenin ihtiyaçlarına göre programlarını yapılandırabilirler. Resmi destekli kredi sigortası kuruluşları, ürünlerinin isimleri, vade ve koşulları, prim oranları ve prosedürleri farklı olmakla birlikte temel programlar uygularlar. Bu kuruluşların verdiği garanti desteği, sigorta veya garanti desteği olarak da adlandırılmaktadır. Resmi destekli ihracat kredi sigortası kuruluşları tarafından düzenlenen kısa vadeli kredi sigortası poliçeleri tedarikçinin tüm açık hesap satışlarını içerecek şekilde birden fazla alıcıyı ( wholeturnover ) teminat altına alabilir veya tek alıcılı (single risk) olarak da düzenlenebilir. Bu kuruluşlar kısa, orta ve uzun vadeli alacak risklerini teminat altına alan poliçeler düzenlerler. Kredi veren kuruluşlar için düzenlenen ve orta ve uzun vadeli tedarikçi kredisini ( supplier credit ) teminat altına alan, tedarikçileri ve finansal kuruluşları ödeme riskine karşı koruyan sigorta poliçeleri düzenlerler. Kredi veren kuruluşlar ihracata bağlı ticari alacakları satın alma yoluna gittiklerinde veya ticari alacağa bağı finansman söz konusu olduğunda, poliçe ödeme riskini teminat altına alan önemli bir ticaret finansmanı aracı haline gelmektedir. Buna ilave olarak bu kuruluşlar, alıcı kredileri ( buyer credit ) programı ile orta ve uzun vadeli risklerle ilgili olarak, başka ülkedeki alııının ya da alıının bankasının ödeme riskini doğrudan üstlenmektedirler. İhracatçılar verilen bu garanti ile ihracat potansiyelini arttırmakta ve bankaları aracılığıyla bu garantiye istinaden teslimatta erken tahsilat imkânı elde etmektedirler. İhracat yapan tedarikçilerin yükleme öncesi finansman ihtiyaçlarının giderilmesine yönelik ticari bankalar tarafından verilen işletme sermayesi finansmanına yönelik krediler için, tedarikçinin ödeme riskini teminat altına alan garantiler düzenlerler. İthalatçının bankası tarafından açılan gayrikabili rücu akreditiflerin banka tarafından ödenmeme riskini, teyit veren banka için teminat altına alan poliçeler düzenlerler. Sınır ötesi ticarette lehtara hitaben düzenlenmiş teminat mektuplarının, lehtar tarafından vadeden önce haksız bir şekilde nakde çevrilme talebi ile karşılaşılması durumunda politik risk sebeplerinden biri olarak kabul edilen bu durumu amir veya teminat mektubunu düzenleyen banka adına teminat altına alan poliçeler düzenlerler. Proje finansmanında ve yapılandırılmış finansman işlemlerinde karşılaşılan ticari ve politik riskleri teminat altına alan sigorta poliçeleri düzenlemektedirler. Yurtdışı finansal kiralama faaliyetleri ile ilgili olarak kiraların zamanında ödenmesini garanti altına alan poliçeler düzenleyebilirler. Yurtdışı ihale süreçlerinde yurtdışı ihale döviz kuru teminatı ile ihaleye giren şirketin verdiği teklifin kabulünden evvel, teklifi veren şirketin ihalede geçerli olan para birimi dışında bir para biriminden teklif vermiş olması halinde, ihale süreci sonuçlanan kadar kurdaki değişimlerden dolayı oluşan kur riskini teminat altına alan poliçeler düzenleyebilirler. Sınır ötesi yatırımlarda karşılaşılan savaş, terör, konvertibilite problemleri gibi politik risklerin yan ısıra, taşınır ve taşınmaz varlıklara yönelik el koyma, millileştirme veya istimlak gibi politik riskleri teminat altına alan politik risk sigortaları düzenlerler. (Grath, 2010)

\section{TEDARIKÇi KREDISININ TICARETIN BÜYÜMESINE ETKISi}

Tedarikçi kredisinin ticaretin büyümesine olan etkisini iki yönlü düşünmek mümkündür. Bunlardan ilki tedarikçi kredisinin hem tedarikçinin satışlarını arttıran hem de alım yapan şirketin kendi ticaretini de sürdürülebilmesine imkân veren bir finansman kaynağı olmasıdır. Alıcı, bu kredi imkânından yararlanarak peşin ödeme yerine vadeli ödeme imkânı elde ederken, kendi müşterisine de vadeli satış yapma imkânı elde edebilir. Diğeri ise, alıcı için bu finansman imkânının işletmenin faaliyetlerini sürdürülebilmesi için banka kredisine alternatif bir finansman kaynağı oluşturmasıdır. Şirketlerin işletme sermayesi finansmanı için ihtiyaç duydukları finansmanın tedarikçinin sağladığı bu kredi imkânı ile ikamesi söz konusudur. Bu nedenle literatür taramasında tedarikçi kredisinin ticaretin büyümesine olan etkisi iki yönlü ele alınmıştır.

Fernando ve Mulier'in, sekiz ayrı Avrupa ülkesinde 1993 - 2009 yıllarına ilişkin 600.000 şirketi kapsayan ve 2,5 milyon küçük ve orta boy işletmeye ilişkin veri içeren çalışmalarında finansal piyasalardaki farklılıklar göz önüne alınarak tedarikçi kredisinin firmaların büyümesine olan etkisi ölçülmeye çalışılmıştır. Çalışmanın sonucuna göre firmalar tedarikçi kredisinden yararlanarak büyümelerini finanse etmektedirler. Fernando ve Mulier'e göre tedarikçi kredisi iki yönde ticareti destekler. Tedarikçi kredili satış yaptığında tedarikçi için ticari alacak söz konusudur. Alıcı ise vadede ödeme yapılana kadar ticari borç taşır. Tedarikçi şirket vadeli satış yaparak satışlarını büyütme çabasındadır. Alıcı üretimini sürdürebilmek için bir finansman 
kaynağı elde etmektedir. Ayrıca, kendi müşterisine de kredili satış yapabilir. Böylece ticari alacak ve ticari borç ilişkisi tüm tedarik zinciri boyunca devam eder. Bu iki yönlü ilişki şirketler arası kredi kanalını birlikte oluşturmaktadır. Firmalar üretimlerini arttırabilmek için alternatif bir finansman kaynağı olarak tedarikçi kredisinden yararlanırlar. Fernando ve Mulier, çalışmalarında tedarikçi kredisinin özellikle finansal sıkışıkların olduğu dönemlerde banka kaynaklarına ulaşmakta zorluk çeken şirketler için önemine ilişkin de tespitlerde bulunmuşlardır. Bu dönemlerde tedarikçi kredisi firmalar için daha önemli hale gelmektedir. Şirketler tedarikçi kredisinden yararlanarak üretimlerini sürdürürler ve ticarete devam edebilirler. Ticaretin sürekliliği sağlanmış olur. (Ferrando,\&Mulier,2013)Boissay ve Gropp, Fransa'da faaliyet gösteren şirketlere ilişkin deneye dayalı verilerle çalışmanın kapsamını genişletmişlerdir. Araştırmalarında firmaların büyümesi ile tedarikçi kredisi kullanımı arasındaki ilişkiyi incelemişlerdir. Likidite problemi yaşan firmalar beklenmeyen şoklarda tedarikçilere olan ödemelerinde temerrüde düşebilirler. Bu firmalar genellikle kredi bulma imkânları bakımından zorluk yaşayan firmalardır. Araştırmanın sonucuna göre, bu firmalar likidite problemlerinin yüzde yirmi beşinden fazlasını tedarikçilerine ödemelerini geciktirerek aktarmaktadırlar. Bu temerrüt zinciri likiditesi yüksek ve finansal piyasalara ulaşmakta zorluk çekmeyen büyük tedarikçi firmalara ulaşıncaya kadar devam etmektedir. (Boissay \& Gopp,2007)

Fisman ve Love, benzer bir çalışmayı yaparak piyasalar arasındaki farklılıklardan hareketle bir görüş geliştirmişlerdir. Az gelişmiş finansal piyasaların bulunduğu ülkelerde tedarikçi kredisinden daha fazla yararlanan sektörlerin daha hızlı bir büyüme gösterdiğini söylemektedirler. (Fisman \& Love, 2003). Nilsen, benzer bir araştırmasında banka kaynaklarına bağımlı olan şirketlerin harcamalarını azaltma yoluyla para politikalarındaki şoklardan daha fazla etkileneceğini göstermiştir. Özellikle küçük ölçekli firmalar için tedarikçi kredisi alternatif bir kredi kanalı olarak öne çıkmaktadır (Nilsen, 1999). Petersen ve Raghuran, $A B D$ pazarında küçük ölçekli firmalara yönelik olarak yaptıkları araştırmada, finansal kuruluşlardan kredi temin etmekte zorlanan şirketlerin tedarikçi kredisinden daha fazla yararlandığını göstermektedirler (Petersen \& Raghuran, 1997). Ogawa, Sterken ve Tokatsu'nun Japonya'daki küçük ölçekli firmalara (KOBi'ler) ilişkin yaptıkları çalışmada elde edilen sonuç banka kredilerine ulaşım imkânının zor olduğu KOBi'lerde tedarikçi kredisine bağımlılığın yüksek olduğu yönündedir. Tedarikçi kredisi КОВi'ler için banka kredisine ciddi bir alternatif oluşturmaktadır. (Ogawa, Sterken, \& Tokutsu, 2013) Chor ve Manova çalışmalarında Amerika'nın yaptığı ithalatın aylık seyrini izleyerek global finansal krizde uluslararası ticari akımlardaki çöküşü incelemişlerdir. Ticaret hacimlerini etkileyen önemli sebeplerden biri kredi koşullarıdır. Yüksek faiz oranlarının olduğu ve sıkışık kredi piyasalarının olduğu ülkeler Amerika'ya daha az ihracat yapabilmektedirler. Bu etki özellikle finansmanda dışarıya bağımlı olan ve tedarikçi kredisinden yararlanamayan sektörlerde veya teminatlandırılması zor olan aktiflere sahip olan sektörlerde daha fazla olmaktadır. Finansal açıdan daha kırılgan endüstrilerin ihracatı, üretimin de bu durumdan olumsuz etkilenmesi nedeniyle, dış finansman maliyetinin yüksekliğinden daha fazla etkilenmektedir. Özellikle finansal kriz döneminde bu etki artmaktadır. Burada çıkarılan sonuç, tedarikçi kredisinin alıcı firmaların üretimlerini ve ihracatlarını arttırmak konusunda alternatif finansman kaynağı olduğu yönündedir. (Chor \& Manova, 2012) Paul ve Guermat, İngiltere için yaptıkları çalışmada benzer bir sonuç elde etmişlerdir. Çalışmalarında kısa vadeli finansman intiyacının tedarikçi kredisine olan talebi arttırdığını ve tedarikçi kredisinin diğer finansman kaynaklarını ikame ettiğini söylemişlerdir. Çalışmanın sonuçlarından bir diğeri de kredi riskinin yüksek olduğu firmaların tedarikçi kredisine daha bağımlı olduğu yönündedir. (Paul\&Guermat, 2009) Qui ve Ge, Çin pazarı için yaptığı çalışmada, devlet ortaklı olmayan şirketlerin, devletin sahip olduğu şirketlere kıyasla daha fazla tedarikçi kredisinden yararlandıklarını ortaya koymuşlardır. Bu şirketler banka kredilerine sınırlı bir ulaşım imkânı elde ettikleri ölçüde büyümelerine yönelik olarak finansman ihtiyaçlarının karşılanmasında tedarikçi kredisinden yararlanmaktadırlar. Qui \& Ge, 2007) Xia, Çin pazarı için yaptığı çalışmada 2007-2008 finansal kriz öncesi ve sonrası dönemi karşılaştırarak firmaların finansman yapısı ile büyüme arasındaki ilişkiyi incelemiştir. 2007-2008 finansal kriz dönemi öncesi tedarikçi kredisinden daha fazla yararlanan firmalar daha fazla büyümektedirler. Ancak, 2007-2008 kriz dönemi sonrası ise tam tersine küçülme gözlenmiştir. (Xia, 2017) Carvalho ve Shiozer, Brezilya için yaptıkları saha çalışmasında, mikro, küçük, orta ölçekli işletmelere ilişkin sonuçları analiz etmişlerdir. Çalışmanın sonuçlarına göre, tedarikçi kredisi, banka kredilerini ikame eden değil, tamamlayan bir finansman kaynağıdır. Tedarikçi kredisinden yararlanma, finansal kuruluşların risk değerlendirme kriterlerine göre firmanın kredi değerliliğini gösteren bir unsurdur. Kredili satışların oranı, ortalama tahsil süresi ve satışlardaki büyüme alıcı tarafından talep edilen kredili alım tutarı ile bağlantııdır. Bu da tedarikçi kredisinin tedarikçi zinciri boyunca aşağı doğru transfer edildiğini göstermektedir. Tedarikçiler, kredili satış yaparak satışlarını arttırmaktadırlar. (Carvalho \& Schiozer, 2015) Sevim, Ekiyor ve Tosyalı, Dünya Bankasının Türkiye, Romanya, Macaristan, Latviya, Litvanya ve Bulgaristan için yaptığı saha çalışmasını kullanarak firmaların finansal kriz döneminde banka kredisi ve tedarikçi kredisi kullanımlarını incelemişlerdir. Bu çalışmanın sonucuna göre finansal kriz döneminde ürün talebindeki azalmaya bağlı olarak tedarikçiler kredili satışa yönelmişlerdir. Böylelikle ticaretlerini sürdürebilme amacını taşımaktadırlar. Tedarik zincirinde tedarikçi kredisinden yararlanan şirketler, bir alt zincire de kredili satış yapma imkânı elde ederler. (Sevim, Ekiyor , \& Tosyalı, 2016)

\section{TEDARIKÇININ KREDi RISKININ SIGORTALANMASI VE IHRACATTA SIGORTA ETKISI}

Tedarikçinin taşıdığı kredi riski, vadeli satış dolayısıyla tedarikçinin mal ve hizmet bedellerini vadesinde tahsil edememe riskidir. Ticarette karşılaşılan bu risk ( ticari risk ), alııının fatura bedelini taraflar arasında belirlenmiş vadede ödememesi veya alıcının iflası halinde ortaya çıkar. İhracat yapan şirket bu riske ilave olarak, alıcının kendi finansal ödeme gücünden bağımsız olarak ortaya çıkan ve alıcının ödeme yapmasını engelleyen politik risklerle karşılaşabilir. Kredi sigortası ile tedarikçi ihracatta karşılaşacağı ticari ve politik riski teminat altına alarak güvenli bir şekilde ticaretini sürdürür. Satışların 
açık hesap ödeme şekli ile gerçekleşmesi durumunda bu risk çok yüksektir. Açık hesap ödeme şekli ile yapılan ticarette, alıcı tarafından tedarikçi lehine bankası aracılığı ile düzenlenen herhangi bir garanti yoktur.

İhracat kredi sigortasının önemini teorik düzeyde ele alan Funatsu'nun çalışması dışında başka bir çalışmaya rastlanılmamıştır. Funatsu, ihracat kredi sigortasının önemini teorik düzeyde açıklamak için belirsizlik altında karar alma teorisinden yararlanmıştır. Model, firma beklentisinin faydanın maksimize edilmesi amacına yönelik olduğu genel kabulüyle başlar. Genel olarak sigorta ekonomisinde bu teori geçerli olmaktadır. Uluslararası pazarlara yönelik olarak belirsizliğin söz konusu olduğu durumlarda firma ihracat yapmak konusunda tereddütte olacaktır. Sigortanın olmadığı durumda ihracat yapma konusunda istek, firmanın riske karşı duyarlılığına bağı olarak ortaya çıkar. Sigortanın olması durumunda ihracatçının kararı optimal ihracat tutarı ile optimal sigorta teminatının seçimi arasında olacaktır. Buradaki belirleyici unsur prim oranının ne olacağı ile ilgilidir. Funatsu, çalışmasında kamu desteğinin de önemine işaret ederek, ülkelerin ihracatı desteklemek konusunda prim oranını bir teşvik unsuru olarak kullanması gerektiğine dikkat çekmiştir. Özellikle risk almaktan kaçınan veya riske duyarlı firmaların sigortaya ihtiyaç duyacakları kabul edilmiştir. Funatsu'nun bu çalışması, riske karşı duyarlılı̆ın, artan riskler dolayısıyla yüksek olduğu durumlarda ihracatın sigortalı yapılması gerektiği konusunu teorik bir çerçevede açıklamaktadır. (Funatsu, 1986)

Aşağıda değişik ülkelerde yapılan araştırmalara yer verilerek, ihracat kredi sigortası kuruluşlarının ihracatı arttırmak konusundaki faaliyetlerine ilişkin elde edilen sonuçlar paylaşıımaktadır:

Ross ve Pike, Kanada'da faaliyet gösteren şirketlerin ihracat kredi müdürleri ile yaptıkları anket çalışması yapılmışlardır. Bu anket çalışmasında firmaların özellikle ihracat işlemlerinde risk yönetim faaliyetlerini nasıl yürüttüklerini analiz etmişlerdir. Kredili satış politikalarında standart uygulamaların dışında, ihracatta karşılaşılan risklerin kredi limitlerinin oluşturulmasında, ödeme şekillerinin belirlenmesinde, riskin taşınma süresinde ve risk tutarının belirlenmesinde dikkate alınıp alınmadığı araştırılmıştır. Ülke risklerinin yurtdışındaki alııının kredi değerliliği hakkındaki görüşlerini değiştirip değiştirmediği veya ihracatta alacak risklerinin kredili satış tekliflerinde dikkate alınıp alınmadığı gibi sorulara cevap alınmaya çalışılmıştır. Araştırma sonuçlarına göre, mevcut kredili satış modelleri kredili ihracat yapma kararını açıklamak konusunda yetersiz kalmaktadır. Mevcut kredili satış karar modelleri sadece ticari alacak risklerini dikkate almakta ve risk değerlendirme kriterleri, riskin yönetilmesinden ziyade, sadece kabul et veya reddet üzerine kuruludur. Bu çalışmanın önemi, ihracata ilişkin risklerin transferine yönelik ihracat kredi sigortası gibi çözümlerin de kredili satış politikalarında dikkate alınması gerekliliğine ilişkin erken tarihli bir saha çalışmasının çıkarımları olmasıdır. (Ross \& Pike, 1997)

Coughlin ve Cartwright ampirik verilerden yararlanarak Amerika için ihracatta devlet desteğinin ihracatı arttırma konusunda etkisini ölçmeye çalışmışlardır. İhracatı destekleme konusunda yapılan harcamaların ihracat üzerindeki olumlu etkisi gözlemlenmiştir. Benzer bir çalışma, (Wilkinson, Keillor , \& d'Amico, 2005) tarafından 1994-2000 yılları arasını kapsayan bir çalışma ile desteklenmektedir. Amerika'da ihracatın desteklenmesi için yapılan devlet harcamalarıyla ihracat arasında olumlu yönde bir ilişki olduğu gözlemlenmektedir. (Coughlin \& Cartwright, 1987)

Alonso ve Levine ve Morga, İspanya için yaptıkları araştırmada, devlet destekli ihracat kredi sigortasının gelişmekte olan ülkelere yapılan ihracat üzerindeki etkisini ölçmeye çalışmışlardır. Çalışmanın sonuçlarından biri ihracat kredi sigortası kuruluşlarının ihracatı arttırmak konusunda limitli bir desteğinin olduğunu göstermektedir. İhracat kredi sigortasının sadece ticari riski teminat altına alması, ihracat yapılan ürünün kalitesi konusunda doğrulama imkânının olmaması, ihracatı teşvik etmek konusunda desteğinin önemini azaltmaktadır. Sigorta verdiği garanti desteği ile düşük kalitede mal ihracatının artmasına sebep olabilir. Düşük kalitede mal satışı ise ithalatçının alım yapma kararını olumsuz etkileyeceğinden ihracatın azalacağı veya olumsuz yönde etkileneceği yönünde bir görüşe varılmıştır. Çalışmada elde edilen bir diğer sonuç ise risk almaktan kaçınan firmaların artan politik riskler dolayısıyla ihracat kredi sigortalarından yararlanmaya devam ettiği yönündedir. (Alonso, Levine, \& Morga, 2004)

Alvarez E. ve Crespi, Şili için yaptıkları çalışmalarında ihracatı teşvik yönünde yapılan uygulamaların ihracatı olumlu yönde etkilediğini ortaya koymuşlardır. Bu çalışmada Şili ihracat kredi sigorta kuruluşunun ( PROCHILE) sunduğu ürün ve hizmetlerin faydasının ölçülmesine yönelik 365 firmayı kapsayan bir saha araştırması yapılmıştır. Araştırma sonucuna göre, kuruluşun desteği sigorta, finansman, uluslararası işbirlikleri ve pazarlama desteği gibi çok yönlüdür. İhracatı arttırmaya yönelik uygulamalar, teknolojik yeniliklerin artmasına sebep olur, yeni ürünlerin piyasaya sunulur ve şirketlere organizasyonel anlamda yenilik getirir. Kuruluşun verdiği destekle, firmaların dış pazarlardaki rekabet gücü artar, yurtdışı firmalarla yapılan anlaşmaları ve işbirlikleri gelişir. Bunun sonucunda yeni personel istihdamı sağlanır, dağıtım ağları oluşturulur ve bilgi işlem alt yapısı için ilave yatırımlar yapılır. Farklılaştııılmış ürünlerin de sunulmasında ihracat kredi sigortası kuruluşunun önemli bir katkısı mevcuttur. Bu çalışmada, ihracat kredi sigortasının ihracata olan etkisi rakamlarla da ölçülmüş, yeni ürünlerle yeni pazarlara ulaşma konusunda ihracat sigortası desteğinin önemli olduğu sonucuna varılmıştır. (Alvarez E. \& Gustavo, 2000)

Abraham ve Dewitt, çalışmalarında resmi ihracat kredi sigortası kuruluşlarının verdiği ihracat garanti desteğinin ihracatı teşvik eden bir unsur olup olmadığını teorik ve ekonometrik bağlamda incelemişlerdir. Bu çalışmada Belçika ihracat kredi sigortası kuruluşu NDD’nin çalışmaları ampirik veriler üzerinden incelenmiştir. İhracata verilen garanti desteğinin ihracatı teşvik ettiği kabul edilir. Bununla birlikte bu desteğin rekabeti azalttığı ve serbest ticaretin yönünü olumsuz yönde 
etkilediğine ilişkin görüşler de mevcuttur. Bununla birlikte özellikle yüksek riskli pazarlara ihracat yapmakta zorlanan firmalar resmi destekli ihracat kredi sigortası kuruluşlarının bu pazarlara yönelik desteği ile güvenli bir şekilde ihracat yapabilmektedirler. Yazarlara göre, makul bir prim oranı yüksek riskli pazarlar için, teşvik kapsamında değerlendirilmemelidir. Belçika ihracat kredi sigortası kuruluşu NDD tarafından sigortalanan ihracat kontratlarında da durum bu şekildedir. NDD prim oranlarının tespitinde ve portföyün bölgesel olarak dağılımında risk bakımından farklılıklar dikkate almakta ve bir özel sektör kredi sigortası kuruluşu gibi çalışmaktadır. (Abraham \& Dewitt, 2010)

Mah, Japonya ile ilgili yaptığı çalışmada ülke ihracat sigorta desteğinin ihracatı arttırıp arttırmadığını incelemiştir. Çalışma sonucuna göre Japonya ihracat kredi sigortası programından büyük ölçüde yararlanan bir ülke olmasına rağmen, birim kök testleri ve koentegrasyon analizi sonucu bu desteğin ihracatın artması yönünde olmadığı sonucuna varılmıştır. Bu sonucun elde edilmesinin sebebi, ihracatçıların bu ihracat desteği ile ihracatı arttırma çabalarının ithalat yapan ülkelerde alınan korumacı önlemleri arttıracağı ve ithalata uygulanan vergileri artırabileceğidir. (Mah, 2006)

Egger ve Url, 2008 yılı ile ilgili olarak, 178 Avusturya şirketine ilişkin veri içeren çalışmalarında, Avusturya ihracat kredi sigortası kuruluşu Kontrollbank (OeKB) tarafından verilen ihracat garantilerinin ihracat üzerindeki etkisini incelemişlerdir. Bu çalışmada büyük şirketlerin yüksek riske maruz kaldıkları ve bu nedenle bu desteğe önemli ölçüde ihtiyaç duyduklarını göstermiş̧ir. Çalışmada, ihracatta sigorta desteğinin ihracatı \% 100 ile \% 130 oranında arttırdığı hesaplanmıştır. (Egger \& Url, 2010)

Moser, Nestmann ve Wedow, Egger ve Url'un Avusturya ihracat kredi sigortası kuruluşu OeKB için ampirik veriler kullanarak yaptığı çalışmanın benzerini Almanya'da Euler Hermes'in Alman hükümeti adına verdiği ihracat kredi sigortası desteği için yapmışlardır. Ancak çalışmalarında ilave olarak finansal friksiyonların etkisini de ölçmeye çalışmışlardır. Böyle dönemlerde ihracatta garanti desteği özellikle artan politik risklerden dolayı önemli hale gelmektedir. Çalışmanın sonucuna göre, ihracat kredi sigortasının ihracatı arttırma konusundaki etkisi oldukça yüksektir. Bu desteğin, ihracatta 1,7 oranında bir çarpan etkisi yarattığı hesaplanmıştır. (Moser, Nestmann , \& Wedow,2008)

Felbelmayr ve Yalçın çalışmalarında, Euler Hermes tarafından yönetilen Alman resmi ihracat kredi sigortası kuruluşunun verileri üzerinden bir çalışma yapmışlardır. Euler Hermes, Almanya hükümeti adına bu desteği veren ihracat kredi sigortası kuruluşu olarak Amerika'dan sonra dünyanın ikinci büyük ihracat kredi sigortası kuruluşu konumundadır. Euler Hermes'den elde edilen 2000-2009 yılına ilişkin veriler ile yapılan bu çalışmada; verilen teminat tutarı, ihracat yapılan ülke, sigortanın şekli, ihracat yapan sektörler gibi değişkenler dikkate alınmıştır. Bu çalışmadan elde edilen sonuç, bu desteğin ihracatı arttırdığı yönündedir. Verilen garantilerde \% 1'lik artış ihracatı \% 0.012 ile $0.017 \%$ oranında arttırmaktadır. Çalışmanın bir diğer sonucuna göre, garanti desteği ile belirli sektörlerin ihracatında daha fazla artış gözlemlenmektedir. Aynı şekilde, ihracatta sigorta desteğinin belirli ülkelere yönelik etkisi daha fazladır. Bu etkinin en yüksek olduğu zamanın, 2008 finansal kriz yılı olduğu ortaya çıkmaktadır. (Felbermayr \& Yalçın, 2010)

Hayakawa, Lee ve Park ihracat garanti desteğinin Japonya ve Kore'nin ihracatının artması konusundaki rolünü incelemişlerdir. Japonya'da Japon Dış Ticaret Organizasyonu ( JETRO ) ve Kore'de Kore Ticari Yatırım Destekleme Ajansı ( KOTRA ) 'nın ihracat garanti desteğini ölçmek için yapılan bu çalışmada 1980-2009 yılları arasındaki verilerden yararlanılmıştır. Çalışmanın sonucuna göre bu iki kuruluşun garanti desteği ile her iki ülkenin de ihracatı olumlu yönde etkilenmektedir. Özellikle düşük gelirli ülkelere yapılan ihracat üzerindeki etkisi ve imalat sanayi için desteği daha fazla olmaktadır. (Hayakawa, Lee, \& Park, 2011)

Zammit, Ross ve Wood, Avustralya'da yaklaşık 1000 firma ile gerçekleştirdikleri ankette ihracat kredi sigortasının önemini sorgulamışlardır. Çalışmanın sonucuna göre, sigorta poliçesiden yararlanan firmaların ihracat ciroları artmaktadır. Bu firmalar, ticaret finansmanı imkânlarına daha kolay ulaşabilmektedirler. (Zammit, Ross, \& Wood, 2009)

Gil, Llorca ve Serrano, İspanya'daki bölgesel ihracat sigorta kuruluşlarının İspanya'nın ihracatını ne ölçüde etkilediğini araştıran bir çalışma yapmışlardır. Araştırmanın sonucuna göre bölgesel kuruluşlar ihracatı arttırma yönünde etkin bir rol oynamaktadırlar. (Gil, Llorca, \& Serrano, 2008)

Eck, Engemann ve Schnitzer, çalışmalarında peşin ödeme ile yapılan satışlara odaklanmışlardır. Almanya'da faaliyet gösteren şirketlere yönelik yapılan bir anket üzerinden peşin ödeme şekli ile yapılan ihracatın, ihracatı arttırmak konusundaki etkisini ölçmüşlerdir. Peşin ödeme, ihracatçı firmalara alıcı tarafından sunulan bir prefinansman kaynağıdır. Firmaların geleneksel banka kredilerinden yararlanmakta güçlük çektikleri dönemlerde önemli bir finansman kaynağıdır. Peşin ödeme ile tedarikçi finansman imkânı sağladığı için üretimini devam ettirip ihracat kabiliyeti elde etmektedir. Global ölçüde parasal sıkışıklıkların görüldüğü dönemlerde, geleneksel banka finansmanından yararlanamayan şirketler için peşin ödemeli ticarette elde edilen finansman üretimin ve ihracatın arttırılması için önemli bir kaynak haline dönüşmektedir. Buradaki çalışmadan şu sonucu çıkarmak da mümkündür. İthalatçıların vadeli alım yapma ihtiyaçları söz konusu olur ise o takdirde ihracatçının alıcıya tanıdığı vade de aynı şekilde ithalatçı için önemli bir finansman kaynağı olacaktır. (Eck, Engemann, Schnitzer, 2014)

Baltensberger ve Herger 1999-2005 yıllarını kapsayan çalışmalarında resmi destekli ihracat sigorta programlarının ticarette riskleri azaltmak konusunda ne ölçüde etkili olup olmadığını ölçmeye çalışmışlardır. Gravity model kullanarak yurtdışındaki 
alıııların temerrüde düşmeleri durumunda ihracatçı firmaların karşılaşabilecekleri finansal zararın tutarını hesaplamışlardır. Çalışmanın sonucu, OECD ülkelerinden geliri düşük ülkelere yapılan ihracatta, ihracatta garanti desteğinin yeterince etkili olmadığını göstermektedir. Hatta yüksek ve orta gelirli ülkelere yapılan ihracatta bile finansal aracıların ve finansal piyasaların riski transfer etmek konusundaki etkisi daha yüksektir. Özellikle OECD ülkelerinin tarihsel olarak kolonyal ilişkide olduğu ülkeler için ihracatta garanti desteği, göreceli olarak daha etkilidir. Bununla birlikte özel sektör kredi sigortası kuruluşlarının düşük gelirli ve gelişmekte olan pazarlara yönelik sigorta desteğinin sınırlı olduğu hallerde, resmi kuruluşların verdiği destek son derece önemli hale gelmektedir. (Baltensperger \& Herger, 2009)

Marticus ve Carballo, Peru için 2001-2005 yılları arasını kapsayan çalışmalarında firma verilerinden yararlanarak, ihracat kredi sigortası kuruluşu PROMPEX'in sigorta desteğinin ihracatı arttırmak konusundaki etkisini ölçmeye çalışmışlardır. Çalışmanın sonucuna göre, ihracat kredi sigortası şirketlere yeni pazarlar bulmak ve yeni ürünlerle bu pazarlara ulaşmak konusunda fayda sağlamaktadır. İhracat kredi sigortası firmaların ihracatlarını arttırma konusundaki son derece etkilidir. (Martincus \& Carballo, 2008)

Lederman, Olarreaga, Payton, 103 gelişmiş ve gelişmekte olan ülkeyi içine alan bir anket çalışmasına göre ihracat sigorta desteğinin ihracatı arttırma yönünde önemli olduğunu söylemişlerdir. İhracatı destekleme konusunda bu kuruluşlar ticaretteki engelleri aşma ve asimetrik bilgi problemini çözme yoluyla ihracatın artmasına destek olmaktadırlar. (Lederman, Olarrega, \& Payton, 2010)

Polat ve Yeşilyaprak, 2000-2015 yıllarını kapsayan çalışmalarında, Türk Eximbank 'ın Türkiye ihracatı üzerindeki etkisini deneysel verilerle ölçmeye çalışmışlardır. 212 ülke için 16 yıllık verilerle panel gravity regresyon analizi ile yaptıkları bu çalışmanın sonucuna göre, ihracat kredi sigortası, ihracatı arttırmak konusunda etkilidir. (Polat \& Yeşilyaprak, 2017)

Auboin ve Engemann, tedarikçi kredisinin ticaret hacmi üzerindeki etkisini makro düzeyde araştırmışlardır. Çalışmalarında 2005-2011 yılları için Berne Union'ın açıkladığı verilerden yararlanmışlardır. Bu analizde sigortalanmış açık hesap ticaret, kredili satışların bir ölçüsü olarak alınmış ve global ticaret hacmi üzerindeki etkisi ölçülmüştür. Berne Union üç aylık bazda, kısa vadeli risklerle ilgili olarak ihracat yapılan ülkeler bazında, kısa vadeli kredi limitlerine ilişkin verileri toplamaktadır. Kredi limiti herhangi bir zamanda kredi sigortası kuruluşunun alabileceği riskin tutarını gösterir. Bu çalışmada kredi limitleri, sigortalanmış kredili satışların bir göstergesi olarak ele alınmaktadır. Bu nedenle kısa vadeli sigortalanmış kredili satışlarla, ithalat yapan ülkelerin toplam ithalatı üzerindeki etkisi analiz edilmiştir. Çalışmanın sonucuna göre sigortalanmış açık hesap ticaret, global ticaret hacmi üzerinde oldukça yüksek bir etkiye sahiptir. Kriz dönemi de dahil olmak üzere, kriz dönemi öncesi ve sonrası sigortanın ihracatı arttırmak konusundaki katkısı oldukça yüksektir. (Auboin \& Engemann, 2014)

Van der Veer, özel sektör kuruluşlarının düzenlediği ihracat kredi sigortasının ticaret hacmi üzerindeki etkisini göstermek amacıyla bir çalışma yapmıştır. Özel sektör kuruluşları için yapılan çalışmalar çok az sayıdadır. Bu çalışmada özel sektör pazarındaki üç büyük şirketin (Euler Hermes, Atradius, Coface) verilerinden yararlanılmıştır. Çalışmanın sonucuna göre, sigortalanmış açık hesap ihracat uluslararası ticaret hacmi üzerinde son derece olumlu bir etkiye sahiptir. Sigortalanmış her 1 Euro'luk ihracat, toplam ihracat üzerinde 1,3 Euro'luk bir çarpan etkisi oluşturmaktadır. Bunun sebeplerinden biri şirketlerin daha evvel riskli gördükleri için ihracat yapamadıkları ülkelere kredi sigortası ile ihracat yapabilme imkânı elde etmeleridir. Diğeri ithalatın açık hesap şeklinde yapılabilmesinin ithalat talebini olumlu yönde desteklemesidir. (Van Der Veer, 2015)

Brunner ve Farinha, 2005-2012 yılları arası için Afrika ve Asya ülkelerini içeren ve panel veri regresyon analizi ile yaptı̆̆ı çalışmada ihracat kredi sigortasının ticaretin gelişimini ne ölçüde etkilediğini incelemişlerdir. Çalışmada Berne Union verileri kullanılmıştır. Auboin ve Engemann'ın ( 2014) çalışmasında yer alan ihracatta riskin dağıtılması ve karmaşıklığın azaltılmasında ihracat sigortası desteğininin önemine değinen çalışmasından yararlanmışlardır. Bu çalışmanın sonucuna göre, ihracat kredi ve sigorta pazarı ile ihracatta çeşitlilik ve karmaşıklık sorunu arasında bir etkileşim olduğu sonucuna varılmıştır. (Brunner\&Farinha, 2014)

Agarwal ve Wang, çalışmalarında Amerikan Eximbank'ın ( US Export-Import Bank - EXIM) ülke ihracatını arttırma konusunda ne ölçüde etkili olduğunu analiz etmişlerdir. 226 ülkeyi ve 94 sektörü içeren ve 2007-2013 yılları arasını kapsayan çalışmalarında panel veriseti kullanarak gravity model ile ülke, sektör ve sene bazındaki farklılıkları dikkate alarak, bu etkinin derecesini hesaplamışlardır. Çalışmanın sonucuna göre, belirli sektörler Eximbank desteğinden daha fazla yararlanmaktadırlar. İhracatta garanti desteği, büyük şirketlerin ihracatını arttırmak konusunda daha etkindir. (Agerwal \& Wang, 2016)

Herger ve Lobsiger, çalışmalarında İsviçre resmi ihracat sigorta garantisi kuruluşu SERV 'in verdiği garantinin ihracatı teşvik etmek konusundaki etkisini analiz etmeye çalışmışlardır. 2006-2008 yıllarını kapsayan veriler ile yapılan bu analizde ihracat sigortası desteğinin ihracatı yaklaşık \% 1 oranında arttırdığı gözlemlenmiştir. Özellikle gelişmekte olan ülkelere yönelik olarak yapılan ihracatta ve kimya ve makina sektörü gibi spesifik sektörler için bu etki daha yüksek olmaktadır. ìhracatta garanti desteğinin en çok Rusya, İran, Türkiye, Meksika ve Endonezya için etkili olduğu belirtilmiştir. (Herger \& Lobsiger, 2010) 
Badinger ve Url, 2008 yılı verileri ile Avusturya'da faaliyet gösteren 178 ihracat firmasını içeren çalışmalarında ihracat kredi sigortasının ihracatı arttırmak konusundaki etkisini incelemişlerdir. Analiz sonucuna göre ihracat kredi sigortası desteği ihracat performansını çok önemli bir oranda arttırmaktadır. Sigortadan yararlanmayan firmalara kıyasla, ihracat performansındaki artış \% 80-100 oranında lehe fark yaratmaktadır. (Badinger \& Url, 2013)

Janda, Michalikova ve Skuhrovec, 1996-2008 yılları arası için, 160 ülkeyi içeren ve panel veri seti kullanılarak yapılan çalışmalarında ülkenin resmi ihracat kredi sigortası kuruluşu CEB'in ülke ihracatını arttırma konusundaki etkisini ölçmüşlerdir. Çalışmanın sonucuna göre bu desteğin etkisi ile ihracatta artış sağlanmaktadır. Artan riskler dolayısıyla ihracat yapmak konusunda tereddütte bulunulan ülkelere yapılan ihracat için sigortanın verdiği teminat son derece önemlidir. Çek Cumhuriyetinin ihracatı ağırlıklı olarak gelişmekte olan Avrupa ülkelerine olduğu için ihracat sigortası desteği de bu ülkelere yöneliktir. (Janda, Michalikova, \& Skuhrovec, 2013)

Bu çalışmalardan da görüleceği üzere tedarikçi kredisi, firma satışlarını arttırarak firmanın büyümesini sağlar. Şirketler arası kredili işlemleri, mal alım ve satımını tetikler ve ticari akımlar oluşur ve büyüme sağlanır. Ticaretin sürdürülebilirliği kredili ticaretin güvenli bir şekilde sürdürülebilmesine bağııdır.

\section{IHRACATIN EKONOMIK BÜYÜMEYE ETKISININ INCELENMESI}

Gelişmekte olan ülkelerde ihracattaki artışın ekonomik büyümeyi artıracağı beklentisi, korumacı politikaların terk edilip, liberal politikaların tercih edilmesinde etkili olmaktadır.

Son dönemlerde, gerek gelişmiş ülkelerde gerekse gelişmekte olan ülkeler açısından ihracat ile büyüme arasında pozitif yönlü ve uzun dönemi kapsayan bir ilişki olduğuna yönelik pek çok akademik araştırma ön plana çıkmıştır. Bu iki değişken arasındaki ilişkiyi inceleyen çalışmalarda sabit korelasyon katsayısı hesaplaması veya ihracat verilerine dayalı elde edilen değişkenler ile tahmini büyüme modellerine ait regresyon yapılması ya da ekonomik büyüme ve ihracat büyümesi arasında nedensellik ilişkisinin araştırılması yönünde ampirik çalışmalar gruplanabilir.

12 ülke verileri kullanılarak ekonomik büyümenin nedenleri üzerinde yoğunlaşılan bir araştırmada büyüme ile ilgili olarak şu temel bulgular saptanmıştır. (Ağayev, 2011)

1-Büyüme ihracatla birlikte iç piyasa olumsuz yönde etkilenmeyecek şekilde mal ve hizmetlerde artış yaşanması olup, gelir seviyesinin düşük olması nedeniyle gelişmemiş veya az gelişmiş ülkelerde yatırımların yetersiz olmasından dolayı ekonomik büyüme gerçekleşememektedir.

2- İhracatla birlikte ülkeye döviz girişi sağlandığı için üretim kapasitesi artmakta buna bağlı olarak da ekonomik büyüme gerçekleşmektedir.

3- Verimli ve uzmanlaşmış sektörlerde performans daha üst düzeyde olduğu için ekonomik büyüme yaşanır.

4- Piyasalarda rekabet halinde olabilmek için teknoloji, yönetim, üretim ve pazarlama gibi konular hakkında bilgi sahibi olunmalıdır.

Gerek Kugler gerekse Parikh ve Stirbu gelişmiş ve gelişmekte olan ülkeler için yaptıkları çalışmalarda; ihracat artış hızı ve gayri safi milli hâsıla değişimi arasında, zaman serisi analizleri yapıımıștır. Araştırma bulguları, ihracatın, gelişmiş ülkeler ve yüksek teknolojik ürünler üreten ülkelerde büyümeyi pozitif yönde etkilediği yönünde olmuştur. Buna karşılık gelişmekte olan ülkelerde, 1980 sonrası dönemde 1980 ila 1989 yılları arasında ihracat artışının ekonomik büyüme üzerine etkisinin olmadığı, 1990 yılından sonraysa ekonomik büyüme, yatırım ve istihdam üzerine etkisinin olduğu görülmüştür. (Kugler, 1991), (Parikh \& Stirbu, 2004)

Bir diğer geniş kapsamlı araştırma ise 10 OECD ülkesinde 1979-2006 döneminde gerçekleştirilmiş ve Fransa, Japonya, Hollanda, İngiltere, İsviçre'de sigortacılık faaliyetlerinden ekonomik büyümeye tek yönlü bir nedensellik ilişkisi olduğu görülmüştür. Ekonomik büyümenin ise sigortacılığa ivme kazandırması yönünde bulgulara da Kanada ve Amerika Birleşik Devletleri'nde rastlanmıştır. (Tsangyao Chang, Chien-Chiang , \& Chi-Hung, 2014)

Asya ülkelerinde gerçekleştirilen çalışmalarda; reel gayri safi yurtiçi hâsıla ve ihracat artış hızı verileri kullanılarak çeşitli araştırmacılar tarafından testler gerçekleştirilmiştir. (P.C.Y., 1987), (A.F., 1987), (J.K., 1991), (J.C., 1995), (M.N., 1998), (E.M., 1999) Bulgular kısa dönem analizlerinde ihracata dayalı büyümeyi destekleyici yönde olmuş ancak uzun dönemli ilişkilerde bir ilişki bulunamamıştır.

Afrika ülkelerinde yapılan araştırmalarda ihracat artış hızıyla Gayri Safi Yurt İçi Hâsıla verileri kullanılarak en küçük kareler yöntemiyle nedensellik testleri yapılmış ve elde edilen bulgulara göre ihracattaki artışın büyümeyi desteklediği ortaya çıkmıştır. (Shigeyoki \& Razafimahefu, 2003)

1993-2009 yıllarını kapsayacak şekilde Euro'nun para birimi olarak geçerli olduğu sekiz ülkede yaklaşık olarak altı yüz bin şirketi kapsayan büyük ölçekli bir çalışmada firmaların kredili satış kanallarını kullanarak büyümeyi yönetebildikleri görülmüş ve banka kredilerinin sıkışık olduğu dönemlerde firmaların yüksek oranda tedarikçi kredisinden yararlandıkları ispatlanmıştır. (Ferrando \& Mulier, 2013) 
BRIC ülkeleri veri seti olarak alınıp gerçekleştirilen bir başka çalışmada temel amaç, Brezilya, Rusya, Hindistan ve Çin'de ihracat ile ekonomik büyüme arasındaki ilişkiyi inceleyerek ihracata dayalı büyüme hipotezinin geçerli olup olmadığı konusunda saptamalar yapmaktır. Analiz sonuçlarına göre, gerek kısa gerekse uzun vadedeki ilişki ihracattan ekonomik büyümeye doğru olarak bulunmuş ve tam tersi bir durumun anlamlı bulunmadığı gösterilmiştir. Buradan yola çıkılarak, ihracata dayalı büyüme hipotezinin BRIC ülkelerinde geçerli olduğu şeklinde yorum yapılmıştır. (Sandalcılar, 2012)

Ülkemizde de dünyadaki örnekleriyle benzer türde yapılan çok sayıda araştırma mevcuttur. Ülkemizde ithalat, ihracat ve ekonomik büyüme arasındaki ilişkilerin 1987-2006 Aralığındaki üç aylık veriler kullanılarak araştııılığı bir çalışmada; ihracata yönelik büyüme stratejileri ile sürdürülebilir ekonomik büyümeye erişim sağlamak için ihracat artışlarını sürekli kılacak yatırım artışlarının ve üretimde katma değeri yüksek olan sanayi sektörlerine doğru geçişin sağlanması gerekmediği yorumu yapılmıştır. (Özer \& Erdoğan, 2006)

inracatın büyümesini tek bir nedensellik ilkesine bağlamayıp birçok teoriye bağlayan çalışmalar da mevcuttur. Ekonomik istikrar ve ihracat ilişkisini temel alan bir araştırmada aşağıdaki sonuçlara ulaşılmıştır. (Şimşek, 2003) Ekonominin gelişmesine yararı yadsınamamakla birlikte yalnızca çıktının artması ihracatı desteklemez veya arttırmaz. Ekonominin istikrarlı olarak büyümesi için ihracat önemlidir çünkü bu şekilde çeşitli ürün ve hizmetler dünya üzerinde daha hızlı bir şekilde yayılma gösterir ve ülke ekonomileri de bu durumdan olumlu olarak etkilenirler. ihracat bir ülkenin ekonomisi üzerinde aşağıdaki nedenlerden dolayı olumlu yönde etki yapar.

-Rekabet avantajı yaratır. Çünkü mallar dünya üzerinde serbestçe dolaşabildiği için etkin bir sistem oluşturur.

-Günümüzde teknolojinin sürekli olarak büyümesi gelişmesi ekonomiyi de olumlu yönden etkiler Bununla birlikte ekonomik büyüme daha hızlı bir şekilde gerçekleşir.

-İç ticarette ve dış ticarette rekabet avantajı yaratır. İç pazara olan talebin artmasıyla birlikte yabancı yatırımlar için daha fazla alan yaratır.

-Dış pazarda sınırsız satış olanakları bulunduğu için ihracat yapmak iç pazarı geliştirir.

-ihracatın olumlu bir etkisi ise döviz üzerindedir. Döviz girdileri arttıkça hem ihracat hem de ithalat bu durumdan olumlu yönde etkilenir.

Bir çalışmada, 1970-2007 döneminde Türkiye'de insan sermayesi, sabit sermaye, ihracat ve ekonomik büyüme arasındaki ilişkiler araştırılmış ve ekonomik büyüme, insan (beşeri) sermaye, sabit sermaye ve ihracat arasında uzun dönemde pozitif ve istatistiksel olarak anlamlı bir ilişkinin varlığı gösterilmiştir. Ayrıca beşeri sermayenin ekonomik büyümede doğrudan bir etkiye yol açmadı̆̆ı, beşeri sermayenin hem sabit sermaye hem de ihracata etki ederek dolaylı yoldan ekonomik büyümeyi artırdığı bulunmuş, ayrıca büyüme üzerinde dış ticaretin etkili olduğu ve ihracata yönelik büyüme hipotezinin geçerli bir yaklaşım olduğu görülmüştür. (Altıntaş \& Çetintaş, 2010)

Farklı dönemleri içermekle birlikte benzer bir başka çalışmada, beşeri sermaye birikimi, ihracat ve ekonomik büyüme arasındaki ilişkiler Türkiye'nin 1960-2004 dönemindeki yıllık reel GSYH, reel ihracat ve yükseköğrenime kayıt miktarı serileri ile analiz edilmiştir. Bu analizden elde edilen başlıca bulgular; Türkiye'de bir taraftan uzun dönemde ihracattaki artış ve beşeri sermaye birikimi, uzun dönemli büyümeyi desteklerken diğer taraftan da GSYH'deki artışın beşeri sermaye birikimini beslediği şeklindedir. Bu bulgular, beşeri sermayeye dayalı içsel büyüme teorisini ve ihracata dayalı büyüme hipotezini desteklemektedir. (Şimşek \& Kadılar, 2010)

Alıcı ve Ural ülkemizde Türkiye ekonomisinin gelişiminde ekonomik büyüme ile ihracat ve yabancı sermaye akımları arasındaki etkileşimi incelemişler ve ihracata dayalı büyüme çerçevesinde, yabancı sermaye akımının ekonomik büyüme üzerine önemli bir etkisinin olmadığı bulgusuna ulaşmışlardır. Nedensellik testi sonuçlarında ihracattaki değişmelerin uzun vadede sanayi üretim endeksini etkilediği ortaya çıkmıştır. (Alıcı \& Ucal, 2003)

İhracat ve büyüme arasındaki nedensellik ilişkisinin incelendiği bir başka araştırmada ihracattan büyümeye doğru nedenselliğin bulunmadığı, ithalattan büyümeye doğru ise nedenselliğin var olduğu gözlemlenmiş olup, ülkemizde araştırmanın gerçekleştirildiği dönemde ihracata dayalı büyüme stratejilerinin geçersizliği ispatlanmıştır. Çalışmada ayrıca ihracat ve büyüme arasındaki nedensellik ilişkisinin yönünün büyümeden ihracata doğru ve tek yönlü olduğu tespit edilmiştir. Çalışmadan elde edilen sonuçlar; Türkiye'de ihracatın büyümeye neden olmadığını göstermesine rağmen, ithalattan büyümeye doğru bir nedensellik ilişkisinin varlığını gösterdiği için araştırılan dönemdeki ekonomik büyümede ithalatın rolünün önemi ortaya çıkmaktadır. İthalattan büyümeye, büyümeden de ihracata doğru ortaya çıkan nedensellik ilişkisi ise dolaylı da olsa ithalatın, ihracatın artırımasında katkısı olduğunu göstermektedir. Ancak yine de ihracattan büyümeye doğru nedensellik tespitinde bulunulmaması, ihracatın ülke ekonomisi açısından önemsiz olması şeklinde yorumlanmamalı ve ihracatın ekonomik büyümeyi sağlayan kanallarını açarak ve bu türde stratejiler geliştirmek gerekmektedir. (Demirhan, 2005) 
Bir başka çalışmada ekonomik büyüme ölçütü, sanayi üretim endeksi alınmış ve ihracatla olan nedensellik ilişkisi araştırılmıştır. Sonuçta, ihracattan büyümeye doğru tek taraflı bir nedensellik ilişsisinin varlığı tespit edilmiştir. (Özmen, Özer, \& Türkyılmaz, 1999)

Başka bir araştırma sonucunda ise, ihracatın, fiyat indeksi ve üretim kapasitesi ile arasında pozitif yönlü bir ilişkisi olduğu ancak girdi fiyatları ile negatif yönlü ilişkisi gözlemlenmiştir. Sözü edilen değişkenlere ticaret reformları ve teknolojik yenilikler değişkenlerinin eklenmesi durumunda ise ihracat arzının önemli derecede bu değişkenlerden etkilendiği bulunmuştur. (Utkulu, Seymen, \& Arı, 2004)

2005'de gerçekleştirilen bir diğer çalışmada ihracat ile gayri safi yurtiçi hasılanın (GSYH) artması arasında uzun bir vadeyi kapsayan nedensellik ilişkisi araştırılmıştır. Sonuçta 1923 - 1979 ile 1980 - 2003 dönemlerinde ihracat ile büyüme arasında uzun dönemli bir ilişki tespit edilememiştir. (Taban \& Aktar, 2005)

Ülkemizde 1980'li yıllara kadar uygulanan ithal ikameci politikalar terk edilip, ihracata dayalı büyüme modeli benimsendikten sonra bu türdeki politikaları uygulayan ülkelerin büyüme hızlarındaki artışa paralel olarak, Türkiye için de söz edilen politika değişikliğinin sonuçlarını ortaya çıkarmaya yönelik olarak araştırmalardan biri de, 1975-2008 dönemi verilerini kullanarak ihracat ile büyüme arasındaki ilişkinin analiz edildiği ve ihracat artışının büyümedeki artışı desteklemediği sonucuna ulaşıldığı araştırmadır. (Takım, 2010)

1980 - 1996 döneminde ihracat ve büyüme değişkenlerinin logaritmik farklarını hesaplayarak gerçekleştirdikleri çalışmalarında büyümeden ihracata yönelik olarak doğru tek yönlü nedensellik ilişkisi gözlemlemişlerdir. (Yiğidim \& Köse, 1997)

1991-2007 dönemini kapsayacak şekilde yapılan bir başka çalışmada ülkemizde doğrudan yabancı yatırımların ve dış ticaret işlemlerinin ekonomik büyümeye olan etkisi araştırılmıştır. Gayri Safi Yurt İçi Hâsıla (GSYiH), doğrudan yabancı yatırımlar, ihracat ve ithalat değişkenleri arasındaki ilişkilere bakılmış ve doğrudan yabancı yatırımların çok güçlü olmasa da ihracat ve ithalatı takip etmesine karşın doğrudan yabancı yatırımlarla ekonomik büyüme arasında güçlü bir nedensellik ilişsisinin bulunmadığı ispatlanmıştır. Buna ek olarak ithalat ve ihracat ile ekonomik büyüme arasında hem karşılıklı hem de ithalattan ihracata doğru tek taraflı bir nedensellik ilişkisinin varlığı tespit edilmiştir. (Yılmazer, 2010)

Başka bir çalışmada ülkemizde 1996-2006 dönemindeki ihracat, ithalat ve ekonomik büyüme ilişkilere bakılmış ve ihracat, ithalat ve ekonomik büyüme arasında uzun vadede bir denge ilişkisi varlığı görülmüştür. Analizler sonucunda kısa dönemde ithalat, ihracat ve ekonomik büyüme arasında iki yönlü olan bir nedensellik ilişkisi tespit edilmiş ve uzun dönemde, ihracattan ithalata, ithalattan ihracata, büyümeden ihracata ve büyümeden ithalata yönelik olarak tek yönlü bir nedensellik ilişkisinin varlığı gösterilmiştir. (Aktaş, 2009)

1989-2011 dönemini kapsayan bir başka çalışmada, ihracat ve ithalatın ekonomik büyüme üzerindeki etkileri üzerinde çalışılmış ve ekonominin gerek büyüme gerekse küçülme gösterdiği her iki dönemde de hem ihracat hem de ithalatın ekonomik büyümeyi olumlu yönde etkilediği gözlemlenmiştir. Bu sonuç ihracata yönelik olan bir sanayileşme modelinin sağlıklı bir model olduğunun da ispatı olmaktadır. (Saraç, 2013)

Amacı, 1987-2007 dönemindeki aylık verilerle ülkemizde ihracat ile büyüme arasındaki ilişkileri ya da ihracata dayalı büyüme hipotezini test etmek olan bir diğer çalışmada ihracat, ithalat, dış ticaret hadleri ve sanayi üretim endeksi değişkenleri arasındaki uzun vadeli ilişkiler değerlendirilmiştir. Sonuçlarda ihracata dayalı büyüme modeli ile bağlantılı şekilde, ihracattan sanayi üretim endeksine doğru tek yönlü bir nedensellik ilişkisine ek olarak, ihracat ile dış ticaret hadleri arasında çift yönlü nedensellik ilişkisi elde edilmiştir. (Bilgin \& Şahbaz, 2009)

Ülkemizde gerçekleştirilen bir başka araştırmada ise 1996-2002 döneminde ekonomik büyümede hem ticari hem de finansal olarak dışa açılmanın uzun vadeli etkisi araştıııarak ticari dışa açıklık ile ekonomik büyüme arasında her iki yönlü olarak bir nedensellik ilişkisinin varlığı ve bununla birlikte finansal dışa açıklı̆ın ekonomik büyüme üzerinde ise herhangi bir etkisinin olmadığı görülmüştür. (Korkmaz, 2014)

Başka bir çalışmada, ülkemizde 2005-2011 döneminde ihracat, ithalat, sanayi üretim endeksi ve reel döviz kuru arasındaki karşılıklı ilişkileri dikkate alınmış ve ihracata dayalı büyüme modelini doğrular nitelikte olarak Türkiye'nin ihracatındaki büyümenin ekonomisini de büyümesine olumlu yönde etki eden bir araç olduğu görülmüştür. Ayrıca ithalattaki artış ise uzun dönemde sanayi üretimini negatif yönlü etkilemektedir. Mal ve hizmet ihracatında yüksek katma değerli ürünlere önem verilmesiyle ve yüksek faiz-düşük kur sarmalından vazgeçilmesiyle uzun dönemde ülkemiz sanayinin gelişiminin olumlu yönde etkileneceği vurgulanmıştır. (Özcan \& Özçelebi, 2013)

Ihracata dayalı büyüme hipotezi temelde üç ana grup altında araştırılmıştır. Bu gruplar; ülkelerarası (cross-country) etkileşim katsayısı kullanılarak yapılan çalışmalar, tahminlere dayalı şekilde en küçük kareler yöntemi temel alınarak yapılan çalışmalar ve son olarak da zaman serisi yöntemleri ile yapılan araştırmalardır. Ülkemizde 2002 yılından itibaren büyüme ihracata dayalı hale geldiğinden gerek ihracat gerekse ekonomik büyüme değişkenlerinin kullanılarak aralarında nedensellik ilişkilerinin araştırıldığı çok sayıda çalışmadan bir diğeri olan Korkmaz'ın çalışmasında, ihracattan büyümeye doğru tek yönlü nedensellik saptanarak, ülke ekonomisinin büyümesi ve iktisadi kalkınmada ihracatın pozitif etkisi gösterilmiş ancak ihracatı 
arttıran ürünlerin ithal hammaddelerle sağlanması durumunda oluşabilecek cari açık tehlikesine dikkat çekilmiştir. (Korkmaz, 2014)

Dış ticaret ile ekonomik büyüme arasındaki ilişki gelişmiş ve gelişmekte olan ülkelerde araştırıldığında Türkiye'nin de aralarında bulunduğu 7 gelişmekte olan ülke ile 12 gelişmiş ülke için dış ticaret ile büyüme ilişkisinin irdelendiği bir diğer çalışmada, büyümeden ithalata ve ihracata doğru bir nedensellik ilişkisi bulunamamakla birlikte, hem gelişmiş hem de gelişmekte olan ülkelerde, ithalat ve ihracattan büyümeye doğru bir nedensellik ilişkisinin varlığına rastlanmıştır. (Gül \& Kamacl, 2012)

\section{SONUÇ}

Dünya ticareti büyük oranda açık hesap ticarete yönelmiştir. Kredi sigortası bu ticareti güvence altına alan bir risk yönetim aracı ve ticaret finansmanı enstrümanıdır. Ticaretin sürdürülebilirliği, tedarik zincirinde ticari akımların sürekliliğinin sağlanmasına bağlıdır. Şirketler arası kredili ticaret, ticari akımların sürekliliğini sağlar. Kredili satış yaparak tedarikçiler mal ve hizmet satışlarını artııırlarken, tedarikçi kredisi alıcılar için bir finansman kaynağı olmaktadır. Tedarikçi kredisinden yararlanan alııılar da kendi müşterilerine kredili satış yapma imkânı elde etmektedirler. Böylece ticari akımlarda büyüme sağlanır. Kredi sigortası ile tedarikçiler, açık hesap ticarette karşılaşabilecekleri ticari ve politik riskleri güvence altına alarak emniyetli bir şekilde büyüme imkânı elde ederler. Alıcılar ise tedarikçi lehine verilecek herhangi bir banka garantisine ihtiyaç duymadan ve banka kredi limitlerini kullanmadan açık hesap bazında mal temin edebilmektedirler. Bu nedenle kredi sigortası kredili ticaretin sürdürülebilirliğinde önemli bir rol oynamaktadır. Yapılan araştırmalarda, tedarikçi kredisinin firma büyümesine etkisi incelenmiştir. Tedarikçi kredisinin firmaların büyümesini olumlu yönde etkilediği ve özellikle finansal kriz dönemlerinde alıcılar için önemli bir finansman kaynağı olduğu sonucuna varılmıştır. Diğer çalışmalarda sigortalanmış açık hesap ticaretin ihracat üzerindeki etkisi ampirik verilerle analiz edilmiştir. Çoğunlukla bu araştırmalarda, ülkelerin resmi destekli ihracat kredi sigortası kuruluşlarının ihracatın artmasına yönelik garanti desteği incelenmektedir. Bununla birlikte özel sektör kuruluşlarının ticaretin gelişimi üzerindeki etkisinin analiz edildiği çalışmalar da mevcuttur. Bu çalışmaların bazıları özellikle 2008-2009 finansal krizinin dünya ticareti üzerindeki olumsuz etkileri düşünülerek bu dönemi kapsayacak şekilde yapılmıştır. Elde edilen sonuçlara göre finansal kriz dönemi dâhil olmak üzere ihracatın artmasına yönelik verilen bu sigorta desteği, ihracatın artırıması konusunda etkili olmaktadır. Özel ve resmi destekli kredi sigortası kuruluşlarının ve çok taraflı finansal kuruluşların derneği olan Berne Union 'ın 2017 yılı için açıkladığı verilere göre bu kuruluşlar ihracatçılara, bankalara ve yatırımcılara 2,3 trilyon ABD Dolarlık ödeme güvencesi vererek, dünyada sınır ötesi mal ve hizmet ticaretinin \% 13 'ünü teminat altına almaktadırlar. Bu ticaretin yaklaşık \% 90'u kısa vadeli ihracat kredi sigortası ile teminat altına alınırken, özel sektör kuruluşlarının bu ticaretteki payı \% 60'dır. Bu rakamlardan da görüldüğü gibi, kredi sigortası kuruluşları dünya ticaretinin gelişiminde önemli bir rol oynamaktadır. Dünya ticaretinin büyümesi ile ekonomik büyüme arasındaki ilişkinin araştıııldı̆̆ı çeşitli araştırmaların sonuçlarına göre ise, ihracat ile ekonomik büyüme arasında pozitif yönlü ve uzun dönemi kapsayan bir ilişki bulunmaktadır. Bu bakımdan, ihracat kredi sigortası kuruluşlarının ihracatın büyümesine yönelik desteğinin aynı zamanda ekonomik büyümenin de sağlanmasına yönelik olduğunu söylemek mümkündür. Ülkemiz ihracatının 2017 yılı itibarıyla yaklaşık \% 64 'ünün açık hesap ( mal mukabili ) ödeme şekli ile yürütüldüğü düşünüldüğünde, Türk Eximbank'ın ve özel sektör ihracat kredi sigortası kuruluşlarının ihracatın gelişimini desteklemek yoluyla ekonomik gelişmeye katkısındaki rol ve önemi ortaya çıkmaktadır. Bu desteğin arttırılmasına yönelik çalışmalar ivedilikle ele alınmalıdır.

\section{KAYNAKLAR}

A.F., D. (1987). Are Exports an Engine of Growth? Another Look at the Evidence. Applied Economics, 19(2), $277-283$.

Abraham, F., \& Dewitt, G. (2000). Export Promotion via Official Export Insurance.Oper Economies Review,11, 5-26. http://doi.org/10.1023/A:11838511974 adresinden alındı

Agarwal, N., \& Wang, Z. (2016). Does the US Eximbank Really Promote US Exports? Reseach Paper 2016/12, 1-33. SSRN Electronic Journal. doi:hhtp://doi.org/10.2139/ssnr.2816468

Ağayev, S. (2011). İhracat ve Ekonomik Büyüme İlişkisi:12 Geçiş Ekonomisi Örneğinde Panel Eşbütünleşme ve Panel Nedensellik Analizleri. Ege Akademik Bakış, 11(2), 241-254.

Aktaş, C. (2009). Türkiye'nin İhracat, İthalat Ve Ekonomik Büyüme Arasındaki Nedensellik Analizi. Kocaeli Üniversitesi Sosyal Bilimler Enstitüsü Dergisi, 18(2), 35-47.

Alıcı, A., \& Ucal, M. (2003). Foreign Direct Investment, Exports and Output Growth of Turkey: Causality Analysis. E. T. Group (Dü.). içinde, (s. 1-19). Madrid. http://www.etsg.org/ETSG2003/paper/alici.pdf

Alonso, D. C., Levine, P., \& Morga, A. (2004). Export Credit Guarantees, Moral Hazard and Exports Quality. Bulletin of Economic Research.311-327, http://doi.org/10.1111/j.1467-8586.2004.00206.x

Altıntaş, H., \& Çetintaş, H. (2010). Türkiye'de Ekonomik Büyüme, Beşeri Sermaye ve İhracat Arasındaki İlişkilerin Ekonometrik Analizi:19702005. Erciyes Üniversitesi İktisadi ve İdari Bilimler Fakültesi Dergisi (36), 33-56. 
Alvarez E., R., \& Gustavo, C. (2000). Exporter Performance and Promotion Instruments: Chielean Emprical Evidence. Estudios de Economia,27(2),225-241.

Auboin, M., \& Engemann, M. (2014). Testing the trade Credit and trade Link: Evidence from Data on Export Credit Insurance,,Review of World Economics. 715-743,doi:http://doi.org/10.1007/s10290-014-0195-4

Badinger, H., \& Url, T. (2013). Export Credit Guarantees and Export performance: Evidence from Austrian Firm level Data,doi:http://doi.org/10.1111/twec.12085

Baltensperger, E., \& Herger, N. (2009). Exporting Against Risk? Theory and Evidence from Public Export Insurance Schemes in OECD countries. Open Economies Review. 20, 545-563. doi:http://doi.org/10.1007/s11079-007-9076-y

Becue. (2013). Credit Insurance What Is It? Why Do You Need It? What Can it Do for Your Business. In Association with Euler Hermes. Lannoo Publishers,88.

Bilgin, C., \& Şahbaz, A. (2009). Türkiye'de Büyüme ve İhracat Arasındaki Nedensellik iliş̧kileri. Gaziantep Üniversitesi Sosyal Bilimler Dergisi, 8(1), 177-198. 8http://sbe.gantep.edu.tr

Boissay, F., \& Gopp, R. (2007)Trade credit Defaults and Liquidity Provision by Firms. Working Paper Series, European Central Bank. https://www.ecb.europa.eu/pub/pdf/scpwips/ecbwp753, 1-42.

Brunner, H. Farinha, J.F. (2014). Testing the Link Between Accessible Export Finance and Insurance and Regional Trade Growth in Africa and Asia, a Role for Regional Export Credit and Investment Guaranty Agency (ECIGA) Asian Development Bank Economics Working Paper Series.1-26 doi:http://doi.org/10.2139/ssrn.2568988

Carvalho, C., \& Schiozer, R. (2015). Determinants of Supply and demand for Trade Credit by Micro Small and Medium Sized Enterprises. Sao Paolo. 208-222, doi:10.1590/1808-057x201500940

Chor, D., \& Manova, K. (2012). Off the Cliff and Back? Credit Conditions and International Trade During the Global Financial Crisis. Journal of International Ecominics, 11-133.

Coughlin, C. C., \& Cartwright, P. (1987). An Examination of State Foreign Export Promotion and Manufacturing Exports. Journal of Regional Science, 439-449.

Cunat, V. (2004). Trade Credit: Suppliers as Debt Collectors and Insurance Providers. Universitat Pompeu Fabra\&Financial Markets Group.146.

Çetiner, M., \& Eke, S. (2018). Güncel Gelişmeler Işığında Kredi Sigortası Pazarı ve Makro Açıdan İrdelenmesi. Social Science Development Journal, 3(12), 496-507.

Demirhan, E. (2005). Büyüme ve İhracat Arasındaki Nedensellik Ilişkisi: Türkiye Örneği. Ankara Üniversitesi SBF Dergisi (60), 75-88.

E.M., E. (1999). Exports and Economic Growth in Asian Developing Countries: Cointegration and Error Correction Models. Journal of Economic Development, 24(2), 43-56.

Egger, P., \& Url, T. (2006). Public Export Credit Guarantees and Foreign Trade Structure: Evidence from Austria.The World Economy, 29(4), 399-418. doi: http:// doi.org/10.1111/j.1467-9701.2006, 00790.x

Felbermayr, G. J., \& Yalçın, E. (2010). Export Credit Guarantees and Export Performance. World Economy, 36(8), 967-999. doi: http:// doi.org/10.1111/twec.12031

Ferrando, A., \& Mulier, K. (2013). Do Firms Use the Trade Credit Channel to Manage Growth? Journal of Banking \& Finance (37), 30353046.

Fisman, R., \& Love, I. (2003). Trade Credit, Financial Intermediary Development and Industry Growth.Journal of Finance,58(1), 353-374. http://www.jstor.org/stable/3094490.

Funatsu, H. (1986). Export Credit Insurance. The Journal of Risk and Insurance, 53(4),679-692, http://www.jstor.org/stable/252970

Ge, Y., \& Qiu J. (2007). Financial Development Bank Discrimination and Trade Credit. Journal of Banking \& Finance,31, 513-530.

Gil, S., Llorca, R., \& Martinez Serrano, J. (2008). Measuring the Impact of Regional Export Promotion. Papers in Regional Science, 87(1), 139146.

Grath. (2010). The Handbook of International Trade and Finance (5. b.). U.K: Kogan Page Limited,110-124.

Gül, E., \& Kamacı, A. (2012). Dış Ticaretin Büyüme Üzerine Etkileri: Bir Panel Veri Analizi. Uluslararası Alanya İşletme Fakültesi Dergisi, 4(3), $81-91$.

Hayakawa, K., Hoon Lee, H., \& Park, D. (2011). Do Export Promotion Agencies Increase Exports. 313, s. 1-19. Institute of Developing Economies, JETRO.

Herger, N., Lobsiger, M. (2010) How Do Export Risk Guarantees Affect Exports? The Case of Switzerland,65(3),297-310

J.C., J. (1995). Export-led Growth and the Four Little Dragons. International Trade and Economic Development, 4(2), $203-215$.

J.K., S. (1991). Rapid Growth in NICs in Asia: Tests of New Growth Theory for Korea. Kyklos, 44(4), 561-579. 
Janda, K., Michalikova, E., \& Skuhrovec, J. (2013). Credit Support for Export: Robust Evidence from The Czech Republic. World Economy,1588-1610, doi:http://doi.org/10.1111/twec.12061

Eck, K., Engemann., M., Schnitzer, M., S. (2014). How Trade Credit Foster Exporting? Review of World Economics, $151(1), 73-101$. doi:http://doi.org/10.1007/s10290-014-0203-8

Korkmaz, S. (2014). Türkiye Ekonomisinde Đhracat ve Ekonomik Büyüme Arasındaki Nedensellik İlişkisi. Business and Economics Research Journal, 5(4), 119-128.

Kugler, P. (1991). Growth, Exports and Cointegration: An Empirical Investigation. Weltwirtschaftliches Archive, 127(2), 73-81.

Lederman, D., Olarrega, M., \& Payton, L. (2010). Export Promotion Agencies. : Do They Work,ournal of Development Economics, 91, 257265 .

Li, Y. (2014). Li Y. et al. (2014) Trade credit insurance, capital constraint and the behaviour of manufacturers and banks. Springer Science and Business Media.

Long M.S, Malitz, I., \& Ravid, S. (1993). Trade Credit Quality Guarantees and Product Marketability. Financial Management, 22(4), $117-127$.

M.N., I. (1998). Exports Expansion and Economic Growth: Testing for Cointegration and Causality. Applied Economics, 30(3), 415-425.

Mah, J. (2006). The Effect of Export Insurance Subsidy on Export Supply: The Experience of Japan. Journal of Asian Economics.646-652, doi: 10.1016/j.asieco.2006.05.004

Martincus, C. V., \& Carballo, J. (2008). Is Export Promotion effective in developing countries? Firm elevel evidence on the intensive and the extensive margins of exports. Journal of International Economics, 76, 89-106. doi:10.1016/jjinteco.2008.05.002

Meltzer, A.H., (1960). Mercantile Credit, Monetary Policy and Size of Firms. The review of Economics and Statistics, 4(429) doi:10.2307/1925692

Moser, C., Nestmann, T., \& Wedow, M. (2008). Political Risk and Export Promotion: Evidence from Germany, The World Economy,781-803. Nilsen, J. H. (1999). Trade Credit and the Bank Lending Channel Working Paper. Swiss National Bank.99(04),1-32.

Ogawa, K., Sterken, E., \& Tokutsu, İ. (2013). The Trade Credit Channel Revisited: Evidence from Micro Data of Japanese Small Firms. Small Bus Econ (40), 101-118. doi:10.1007/s.11187-011-9344-5

Özcan, B., \& Özçelebi, O. (2013). İhracata Dayalı Büyüme Hipotezi Türkiye İçin Geçerli mi? Yönetim ve Ekonomi, 20(1), 1-14.

Özdemir, M. (1999). Finansal Yönetim. İstanbul: Türkmen Kitabevi.

Özer, M., \& Erdoğan, L. (2006). Türkiye'de İhracat, İthalat Ve Ekonomik Büyüme Arasındaki İlişkilerin Zaman Serisi Analizi. Ekonomik Yaklaşım, 17(60-61), 93-110.

Özmen, A., Özer, M., \& Türkyılmaz, S. (1999). Türkiye'de İhracat ve Ekonomik Büyüme Arasındaki Nedenselliğe İlişkin Bir Uygulama Denemesi. Marmara Üniversitesi Yayınları (640), 379-392.

P.C.Y., C. (1987). Causality Between Export Growth and Industrial Development. Journal of Development Economics, 26(1), 55-63. doi:https://doi.org/10.1016/0304-3878(87)90051-4

Parikh, A., \& Stirbu, C. (2004). Relationship Between Trade Liberalisation, Economic Growth and Trade Balance: An Econopmetric Investigation. http://www.hwwa.de/Publikationen/Discussion_paper/2004/282.pdf,(15/06/2005).

Paul, S., Guermat, C. (2009). Trade Credit as Short-Term Finance in the UK. Centre for Global Finance Working Paper Series,1-30.

Petersen, M. A., \& Raghuran, G. (1997). Trade Credit: Theories and Evidence. The Review of Financial Studies, 3, 661-691.

http://www.jstore.org/stable/2962200

Polat, A., \& Yeşilyaprak, M. (2017). Export Credit Insurance and Export Performance: An Empirical Gravity Analysis for Turkey. International Journal of Economics and Finance (12-24).

Ross, D., \& Pike, R. (1997). Export Credit Risks and the Trade Credit Offer: Some Canadian Evidence. Journal of Multinational Financial Management, 55-70.

Sandalcılar, A. R. (2012). BRIC Ülkelerinde Ekonomik Büyüme ve İhracat Arasındaki İlişki: Panel Eşbütünleşme ve Panel Nedensellik. Süleyman Demirel Üniversitesi IïBF Dergisi, 17(1), 161-179.

Saraç, T. B. (2013). íhracat ve ithalatin Ekonomik Büyüme Üzeríndekí Etkísí: Türkiye Örnegi. Ege Akademik Bakış, 13(2), $181-194$.

Sevim, C., Ekiyor, A., \& Tosyalı, A. (2016). As A Supply Chain Financing Source, Trade Credit and Bank Credit Relationship During Financial Crises from Clustering Point of View. International Business Research, 9(4), 45-57.

Shigeyoki, H., \& Razafimahefu, I. (2003). Trade and Growth Relationship: Some Evidence from Comoros, Madagaskar, Mauritius and Seychelles. http://www.asafas.kyoto_u.ac.jp/asafbook/pdf/no_03/p174_185.pdf

Smith. (1987). trade Credit and Informational Asymmetry. The Journal of Finance, 42(4), 863-872.

Şimşek, M., \& Kadılar, C. (2010). Türkiye'de Beşeri Sermaye İhracat ve Ekonomik Büyüme Arasındaki İlişkinin Nedensellik Analizi. C.Ü. İktisadi ve İdari Bilimler Dergisi, 11(1), 115-139. 
Şimşek, M. (2003). İhracata Dayalı-Büyüme Hipotezinin Türkiye Ekonomisi Verileri Ile Analizi, 1960-2002. D.E.ü.iïBF Dergisi, 18(2), 43-63.

Taban, S., \& Aktar, i. (2005). An Empirical Examination of the Export Led-Growth Hypothesis in Turkey. International Conference on Business Management and Economics. İzmir.

Takım, A. (2010). Türkiye'de GSYiH ile İhracat Arasındaki Illişki: Granger Nedensellik Testi. Atatürk Üniversitesi Sosyal Bilimler Enstitüsü Dergisi, 14(2), 315-330.

Tsangyao Chang, Chien-Chiang, L., \& Chi-Hung, C. (2014). Does Insurance Activity Promote Economic Growth? Further Evidence Based on Bootstrap Panel Granger Causality Test. The European Journal of Finance, 20(12), 1187-1210.

doi:http://dx.doi.org/10.1080/1351847X.2012.757555

Utkulu, U., Seymen, D., \& ArI, A. (2004). Export Supply and Trade Reform: The Turkish Evidence. International Conference on Business Management and Economics, (s. 262). http:www.ecomod.net/conferences/ecomod2004/ecomod2004_papers/262, pdf

Van Der Veer, K. (2015). The Private Export Credit Insurance Effect on Trade, Journal of Risk and Insurance. 601-624. doi:http://doi.org/10.1111/jori.12034

Wieczorek, M. (2005). The Role of Credit Insurance in Accounts Receivable Management. https://www.ekf.vsb.cz/export/sites/ekf/frpfi/cs/archiv/rocnik-2005/prspevky/dokumenty/wieczorekmonika.pdf

Xia, J. (2017). Trade Credit, Financing Structure and Growth.,1-81.

Yiğidim, A., \& Köse, N. (1997). İhracat ve Ekonomik Büyüme Arasındaki ilişki, Itthaaltın Rolü: Türkiye Örneği (1980-1996). Ekonomik Yaklaşım (8), 71-85.

Yılmazer, M. (2010). Doğrudan Yabancı Yatııımlar, Dış Ticaret ve Ekonomik Büyüme illişkisi: Türkiye Üzerine Bir Deneme. Celal Bayar Üniversitesi SBE, 8(1), 241-260.

Zammit, B., Ross, D., \& Wood, D. (2009). Perceptions of export credit insurance. Asia- Pacific Journal of Business Administration, 1(2), 109118. doi:http://doi.org/10.1108/17574320910989078 